\title{
TESTING THE FUNCTIONAL TRAINING IN THE MILITARY PENTATHLON AT THE 50 M RACE WITH OBSTACLES
}

\author{
Ioan Sabin SOPA \\ sopa_sabin@yahoo.com \\ Marcel POMOHACI \\ marcelpomohaci@yahoo.com \\ “LUCIAN BLAGA” UNIVERSITY, SIBIU, ROMANIA
}

\begin{abstract}
Nowadays sports success has become more than improving technique, medicine has long been a complementary science technology that improved sports performance. In our study we analyzed the importance of functional training in the military pentathlon at the $50 \mathrm{~m}$ swimming with obstacles. The scientific methods used were the observation method and also the experiment method in which we tested two samples of military students both consisted in 30 students with the age between 18-22 years old, the first group were the experiment group that practice the military pentathlon and the second group - the control group - were simple military students. The results showed significant statistical differences between the experiment group compared with the control group at the final testing, the students from the experiment group had better results in the respiratory rate and vital capacity both compared with the control group and also between the initial and final test. Conclusions of the research showed that the training program implemented at the experiment group has improved significant from the initial to the final test and also compared with the control group.
\end{abstract}

\section{KEYWORDS:}

Functional testing, military pentathlon, military sport, $50 \mathrm{~m}$ race with obstacles

\section{Introduction}

The area of the military pentathlon has developed spectacularly from one edition to the next. "Today, more than 30 nations are present in the circuit of international pentathlon competitions. Most of the time the military pentathlon is included in the World Military Games" (Ene, 2003, p. 205).

The theoretical basis - The results of the scientific researches elaborated in recent years by numerous authors broadened the area of representations about the educational potential of physical education in military higher education (Drăgănescu, 2000; Dragnea, 2002; Rîşneac, Milici \& Rață, 2004). "The complex psychomotor and personality qualities have a formative role in the educational process of the future component of a military representative team” (Epuran, 2001, p. 324). 
Better function of every system in the human body is achieved by regular exercise. "Muscular strength in general (including respiratory muscles) is developed by systematic training, so it is assumed that it has a positive effect on the lung function" (Lazovic-Popovic et al., 2016, p. 152).

"Functional Capacity (FC) represents the highest probable level of activity that a person may reach at a given moment in a standardized environment" (Soer, 2008, p. 190; WHO, 2001).

Some recent scientific research observed that some particular sport disciplines improve the lung function and the cardiovascular capacity better than others, these include swimming, and, as recently reported, basketball, water polo and rowing (Lazovic et al., 2015; Bougault et al., 2009; Vaithiyanadane et al., 2012). Also swimmers achieve larger lung volumes and higher functional cardiorespiratory system capacity compared to other athletes (Lazovic-Popovic et al., 2016).

The physical fitness factor that coaches consider most important in the training of swimmers is endurance. "Endurance is related to the increase in hypertrophy or tension of the cardiac muscle, thereby resulting in transfer of more nutrients and oxygen to the working muscle" (Vasile, 2014, p. 232). "Traditionally, the continuous incremental test was used in the laboratory for measuring the aerobic capacity for endurance, mainly providing results such as maximal aerobic capacity, $\mathrm{VO}_{2} \max$, and lactate threshold" (Faude et al., 2009, p. 471).

\section{Objectives of the research}

The objectives of our research were focused on testing functional parameters of military students that participate in the $50 \mathrm{~m}$ swimming pentathlon with obstacles. The research consisted in applying both functional capacity and respiratory tests, following the development of motor qualities (speed, strength, coordination and resistance) and also finding new ways of training the military students for the $50 \mathrm{~m}$ swimming pentathlon with obstacles.

\section{Material and method}

\subsection{Research sample}

In our research we used two groups, the first group, the experiment group, was formed by 30 military students with age between 18-22 years old components of the pentathlon military team, the second group, the control group, was formed by 30 military students with the same age between 18-22 years old that practice military physical education.

\subsection{Research methods \\ Functional Capacity Testing}

Two measuring techniques were used for the respiratory apparatus where it was checked: respiratory rate and vital capacity.

Measuring instruments used: spirometer and stopwatch. Spirometry is the crucial respiratory function assessment test, as a standardized and reproducible method for estimating the respiratory mechanism and pulmonary ventilation. Spirometric values determined in athletes usually refer to standards (i.e. standardized predicted values) for the average population of healthy subjects, as recommended by international organizations, such as the European Respiration Society (ERS), European Commonwealth of Coal and Steel (ECCS) or the American Thoracic Society (ATS) (Pellegrino et al., 2005; Miller et al., 2005).

Respiratory frequency is measured by the palpation method, with mean values at rest of $12-18$ breaths/minute. It is measured in breaths/minute. The vital capacity is measured with the spirometer, expressed in cubic centimeters $\left(\mathrm{cm}^{3}\right)$.

\section{Results \\ Analyzing and interpreting data in functional capacity tests (experimental stages 1 and 2)}

In Table no. 1 and Table no. 2 we can find the results statistically processed at the functional tests. From the comparative study of the parameters under investigation (respiration frequency, vital capacity), the significance stage of 0.05 and the degree of freedom studied were observed: $\mathrm{n}-1$, insignificant differences. 
Table no. 1

Comparative analysis of group average characterizing the functional capacity of military students initially tested in the experimental stage

\begin{tabular}{|c|c|c|c|c|c|}
\hline \multirow{2}{*}{$\begin{array}{c}\text { No. } \\
\text { Chr. }\end{array}$} & \multirow{2}{*}{$\begin{array}{c}\text { Compared } \\
\text { parameters }\end{array}$} & The control group & The experiment group & “t” & "p" \\
\cline { 3 - 6 } & $\begin{array}{c}\text { Respiratory } \\
\text { Frequency (r/min) }\end{array}$ & $15.10 \pm 0.11$ & $15.00 \pm 0.07$ & 0.76 & $>0.05$ \\
\hline 2 & $\begin{array}{c}\text { Vital Capacity } \\
(\mathrm{cm} 3)\end{array}$ & $3450 \pm 3.85$ & $3560 \pm 3.08$ & 1.94 & $>0.05$ \\
\hline
\end{tabular}

Table no. 2 Comparative analysis of group average characterizing the functional capacity of the military students finally tested in the experimental stage 1

\begin{tabular}{|c|c|c|c|c|c|}
\hline \multirow{2}{*}{$\begin{array}{c}\text { No. } \\
\text { Chr. }\end{array}$} & \multirow{2}{*}{$\begin{array}{c}\text { Compared } \\
\text { parameters }\end{array}$} & \multicolumn{2}{|c|}{$\bar{X} \pm m$} & \multicolumn{2}{|c|}{ Criteria } \\
\cline { 3 - 6 } & The control group & The experiment group & "t" & "p" \\
\hline 1 & $\begin{array}{c}\text { Respiratory } \\
\text { Frequency (r/min) }\end{array}$ & $14.70 \pm 0.11$ & $14.40 \pm 0.07$ & 1.19 & $>0.05$ \\
\hline 2 & $\begin{array}{c}\text { Vital Capacity } \\
(\mathrm{cm} 3)\end{array}$ & $3600 \pm 3.85$ & $4000 \pm 3.08$ & 2.59 & $>0.05$ \\
\hline
\end{tabular}

At final testing, at this experimental stage, the result averages show changes to increase functional performance. Based on the comparative analysis of the group average characterizing the functional capacity, we achieved the dynamics of the results obtained in experimental stage 1 (Figure no. 1).

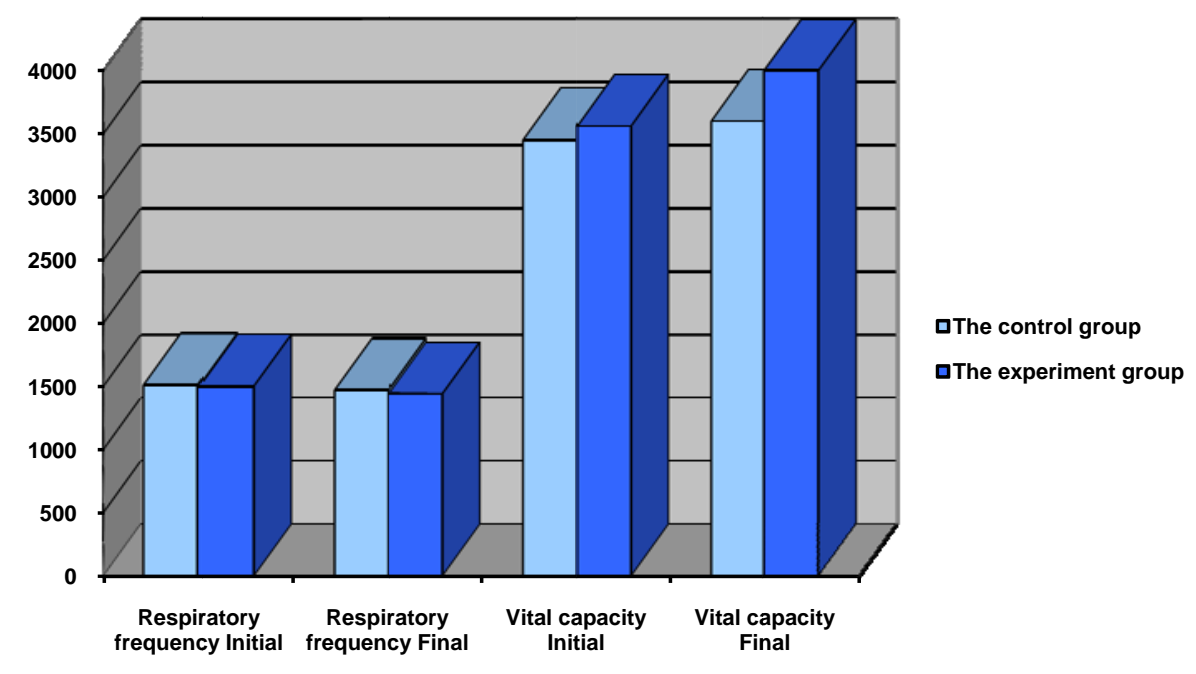

Figure no. 1. Dynamics of functional capacity test results in the experimental stage 1 
From the graphical representation made on a scale of $10 \%$ for greater appreciation to distinguish the near values, we note that for one of the parameters compare: the vital capacity, the average of the results shows significant increases in the final test, $4000 \mathrm{~cm}^{3}$, in favor of the experimental group. By calculating the statistical significance of the difference between the meanings in the final test between the two samples, we note that at the degree of freedom $n-1, p=0.05$, the difference is significant $(\mathrm{t}=2.59>2.13)$ in favor of the experimental sample. This demonstrates that the functional vital capacity parameter, particularly important in the military pentathlon in the obstacle swimming test, has improved due to the specially applied global exercise method. The scientific direction of the instructiveeducational process is based on the knowledge of the functional state of the organism. In the second stage of the research, the processing and statistical analysis were performed following the application of the two parameters: respiration frequency and vital capacity. From the data recorded at the initial testing, the calculation of the difference between the medians shows significant values in favor of the experimental group at n-1, $\mathrm{p}=0.05$, at the vital capacity parameter. In the final test (Table no. 4), the mean values show changes to the functional parameters studied. Thus, the average respiratory capacity outcome at the final test was 14.40 per minute for the experimental group subjects and 14.70 per minute for the control sample. The calculation of the mean difference between averages shows in the final test an insignificant difference, expressed by $t$ with $2.59<2.13$, at $p=0.05$. The averages of the results for vital capacity continued to show gradual increases on the axis of the ordinances in favor of the experimental sample (vital capacity $4000 \mathrm{~cm}^{3}$ ). The results recorded in Table no. 4 were the reference data for the graphical presentation. As can be seen in Figure no. 2, the mean values of vital capacity at the end of our research have the following values: $4000 \mathrm{~cm}^{3}$ for the experimental group, with $400 \mathrm{~cm}^{3}$, more than the average, obtained by the control group subjects, $3600 \mathrm{~cm}^{3}$.

Table no. 3

Comparative analysis of group average characterizing the functional capacity of military students initially and finally tested in the experimental phase 2 initial testing

\begin{tabular}{|c|c|c|c|c|c|}
\hline \multirow{2}{*}{$\begin{array}{c}\text { Nr. } \\
\text { Chr. }\end{array}$} & \multirow{2}{*}{$\begin{array}{c}\text { Compared } \\
\text { parameters }\end{array}$} & \multicolumn{2}{|c|}{$\bar{X} \pm m$} & \multicolumn{2}{c|}{ Criteria } \\
\cline { 3 - 6 } & The control group & The experiment group & “t” & “p” \\
\hline 1 & $\begin{array}{c}\text { Respiratory } \\
\text { Frequency (r/min) }\end{array}$ & $14.70 \pm 0.11$ & $14.40 \pm 0.07$ & 1.19 & $>0.05$ \\
\hline 2 & $\begin{array}{c}\text { Vital capacity } \\
\text { (cm3) }\end{array}$ & $3600 \pm 15.41$ & $4000 \pm 11.55$ & 2.59 & $<0.05$ \\
\hline
\end{tabular}

Table no. 4

Final test

\begin{tabular}{|c|c|c|c|c|c|}
\hline \multirow{2}{*}{$\begin{array}{c}\text { Nr. } \\
\text { Chr. }\end{array}$} & \multirow{2}{*}{$\begin{array}{c}\text { Compared } \\
\text { parameters }\end{array}$} & The control group & The experiment group & “"”t & “p” \\
\cline { 3 - 6 } & $\begin{array}{c}\text { Respiratory } \\
\text { Frequency (r/min) }\end{array}$ & $13.20 \pm 0.15$ & $13.00 \pm 0.15$ & 2.37 & $<0.05$ \\
\hline 2 & $\begin{array}{c}\text { Vital capacity } \\
(\mathrm{cm} 3)\end{array}$ & $4000 \pm 23.11$ & $4450 \pm 11.55$ & 3.87 & $<0.01$ \\
\hline
\end{tabular}




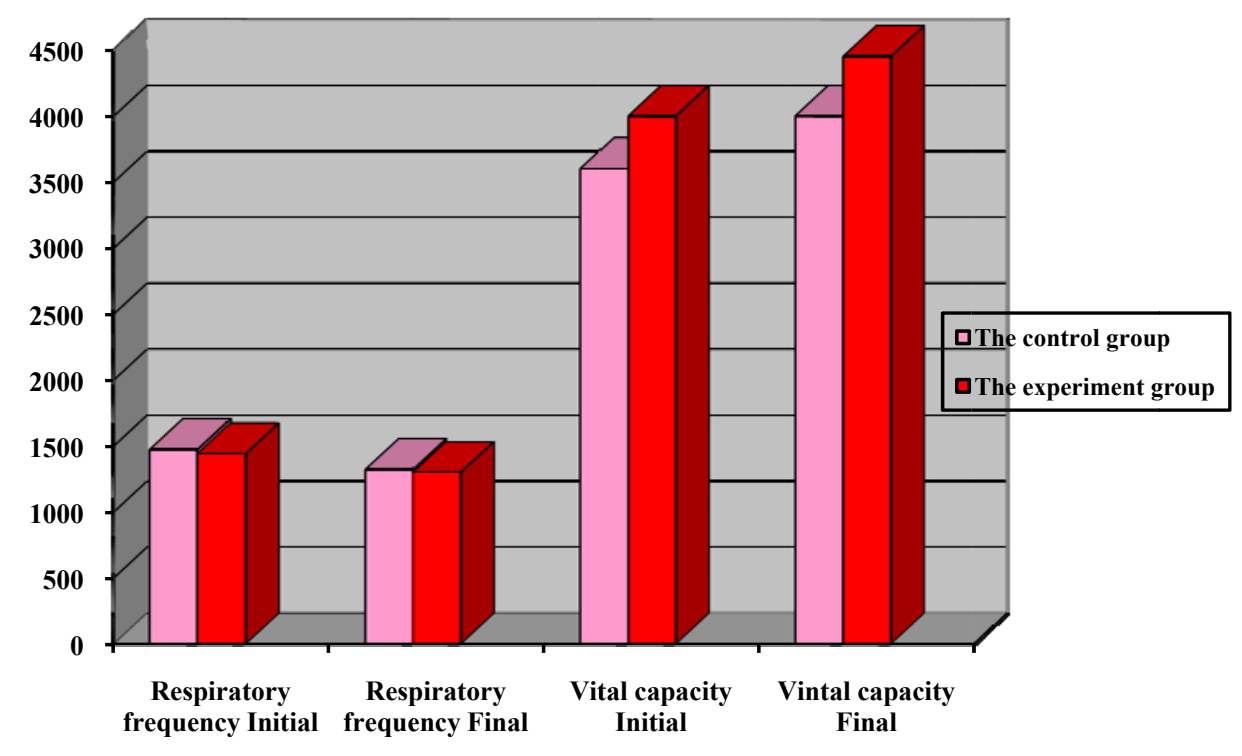

Figure no. 2. Comparative analysis of group average characterizing the functional capacity of military students initially and finally tested in the experimental phase 2 Initial testing

\section{Discussions}

In this test the difference between the average of the results of the two samples is expressed by $3.87>2.95$, at $\mathrm{p}=0.01, \mathrm{n}-1$, the difference being statistically significant. From the analysis of the group averages that characterize the functional capacity of the military students, we can see that the average of the results in the functional capacity tests, which were applied at different moments of our research, progresses from one stage to the other at $n-1, p=0.01$. The increase in the average of the functional parameters subjected to the research confirms the good training of the students, respectively the functional viability of the experiment.

Recent studies have shown that athletes have larger capacity of the respiratory system when compared to their age-matched sedentary controls (Mazic et al., 2015). Higher volumes of vital capacity, forced vital capacity and forced expiratory volume were found in swimmers compared to both the football players and the control group (measured in liters and in percentages).
The results of the present study support the previously published work which showed increased lung volumes in swimmers compared to land based sport disciplines and sedentary controls (Lazovic-Popovic et al., 2016).

\section{Conclusions}

Applying representative tests to develop functional capacity have statistically demonstrated that the media have increased significantly in favor of the experimental group at the two parameters studied. The set of values for statistical significance is $t=3.87$ for vital capacity (at significance degree $n-1, p=0.01$ ).

Conclusions of the research showed that the training program implemented at the experiment group for improving the results of the military pentathlon in the 50 $\mathrm{m}$ swimming with obstacle event has improved significant from the initial to the final test and also compared with the control group. Also the functional testing had helped us monitor the development and efficiency of our training. 


\section{REFERENCES}

Bogault, V., Turmel, J., Levesque, B., \& Boulet, L. P. (2009). The respiratory health of swimmers. Journal of Sports Medicine, Vol. 39, Issue 4, 295-312.

Drăgănescu, E. (2000). Optimizarea conţinutului educaţiei fizice privind pregătirea profesional aplicativă a studenţilor de la universităţile de medicină în baza intensificării procesului de studii. Thesis, Chişinău.

Dragnea, A. (2002). Teoria Educaţiei Fizice şi a Sportului. Bucureşti: Editura FEST.

Ene, V. (2003). Orientări moderne în antrenamentul sportiv din pentatlonul militar. Constanța: Editura Academiei Navale "Mircea cel Bătrân".

Ene-Voiculescu, V., \& Ene-Voiculescu, C. (2016). Operative systems specify to the training in military pentathlon. The $22^{\text {th }}$ International Scientific Conference KnowledgeBased

Organization, Vol. XXII, Issue 1, DOI: 10.1515/kbo-2016-0005.

Epuran, M. (2001). Psihologia sportului de performanţă. Bucureşti: Editura FEST.

Faude, O., Kindermann, W., \& Meyer, T. (2009). Lactate threshold concepts: how valid are they?. Sports Med, Vol. 39, Issue 6, 469-490.

Lazovic-Popovic, B., Zlatkovic-Svenda, M., Durmic, T., Djelic, M., Djordjevic Saranovic, S., \& Zugic, V. (2016). Superior lung capacity in swimmers: Some questions, more answers!. Revista Portuguesa de Pneumologia, Vol. 22, Issue 3, 151-156.

Mazic, S., Lazovic, B., Djelic, M., Suzic-Lazic, J., Djordjevic-Saranovic, S., \& Acimovic, T. (2015). Respiratory parameters in elite athletes - does sport have an influence?. Revista Portuguesa de Pneumologia, Vol. 21, Issue 4, 192-197.

Miller, M. R., Hankinson, J., Brusasco, V., Burgos, F., Casaburi, R., \& Coates, A. (2005). ATS/ERS Task Force Standardisation of spirometry. European Respiratory Journal, Vol. 26, Issue 2, 319-338.

Pellegrino, R., Viegi, G., Brusasco, V., Crapo, R. O., Burgos, F., \& Casaburi, R. (2005). Interpretative strategies for lung function tests. European Respiratory Journal, Vol. 26, Issue 5, 948-968.

Rîşneac, B. V., Milici, D., \& Rață, E. (2004). Utilizarea tehnicii de calcul în evaluarea performanţelor sportive. Brașov: Editura Universității Transilvania.

Soer, R., Van der Schans, C. P., Groothoff, J. W., Geertzen, J. H., \& Reneman, M. F. (2008). Towards consensus in operational definitions in functional capacity evaluation: a Delphi Survey. Journal of Occupational Rehabilitation, Vol. 18, Issue 4, 389-400.

Vaithiyanadane, V., Sugapriya, G., Saravanan, A., \& Ramachandran, C. (2012). Plumonary function test in swimmers and non-swimmers - a comparative study. International Journal of Biological Medicine Research, Vol. 3, Issue 2, 1735-1738.

Vasile, L. (2014). Endurance training in performance swimming. Procedia-Social and Behavioral Sciences, Vol. 117, 232-237.

World Health Organization. (2001). ICF: International Classification of Functioning, Disability and Health. Geneva: Author. 